\section{Where next the dollar?}

The calamitous slump of the US dollar is no more welcome because expected.

THOSE who now wonder why the US dollar should have lost 40 per cent of its value against the Japanese yen since the beginning of the year should have been reading Nature or a reputable economic journal all the time. The underlying causes are the federal government's budget deficit, likely to be $\$ 150,000$ million this year (whatever Gramm-Rudman says it should be next year), and the US population's belief that it has better things to do with its after-tax income than lend it to the government (or the other institutions, such as the financial institutions, from which the federal government borrows). Hitherto, the mismatch and the instability that it entails has not mattered very much. People elsewhere, corporate and private, have been willing to bridge the gap. The Japanese have had enough surplus cash both to drive the Tokyo Stock Exchange to unknown peaks and to snap up assets in the United States, making paper fortunes for their owners which then find their way to the US Treasury. Those oil-producers still in surplus have followed suit. The arithmetical result has been an imbalance in the external trade accounts of the United States.

Many in the US government appear to have believed that this genteel process could continue indefinitely, although that was always an absurdity; there must always have been a numerical upper limit to the net worth of the United States. Since the beginning of 1986 , the markets have been correcting the twin imbalances in the only way they know, by depreciating the dollar and appreciating the currencies of the surplus countries. It is a remarkable testimonial to the productiveness of the US economy that this trend should not sooner have dried up the flow of investment into the United States; people do not ordinarily like buying assets whose value promptly falls.

What seems this year to have broken the spell is the administration's budget for the financial year whose beginning is still half a year away, and which seemed to many to be as artificial a way of meeting the interim Gramm-Rudman target deficit as that the US Congress is likely to adopt in a preelection year. The final straw has been the wild talk in Washington about sanctions against Japan. The \$300-millionworth of goods on which penal tariffs may eventually be levied are numerically irrelevant; what has stuck in the craw of market-traders elsewhere is the demonstration that the United States does not understand the dilemma in which it has placed itself - that one cannot run a budget deficit and a low savings ratio without a matching trade deficit.

The danger now, not just for the United States, is multivalent. Domestically, inflation and interest rates may rise, further slowing industrial activity and slicing substantial portions off recent paper fortunes. Second, the volume of world trade may precipitously decline, with the consequence that countries in poor shape already will be even worse off. Third, and worst of all, these short-term changes could precipitate the most threatening instability of all - the huge indebtedness (exceeding $\$ 500,000$ million) of the world's debtor nations to the world's commercial banks. People worry when the engine of the free market, the US economy, falters by a per cent or so. What would be the deflationary consequences if paper assets equivalent to 10 per cent of its annual production suddenly proved worthless? Whatever happens, there will be a lot to learn from the turbulence of the past few months; economists (and national treasurers) may be persuaded that, if they want to control the international economy, they had better seek to control rates of change than numerical parities.

Mercifully, there are more immediate lessons to be learned, many of them in Washington. If the key to the present instability is the budget deficit, it must surely help to keep the deficit, now and in the future, as small as possible. The administration has had to use some sleight of hand to keep the projected deficit for next year within the Gramm-Rudman limit of $\$ 140,000$ million, but the Congress overrode (last month) a presidential veto on its Highway Bill that will make the target even less attainable. Yet, curiously, this happening has been presented as a political defeat for the White House rather than as a serious setback for the US economy. It is as if the administration, which professes its belief that the deficit is important, does not believe that the numbers are significant. How else, for example, could Mr Caspar Weinberger, the US Secretary of Defense, have last week written a letter to the Secretary of State (see Nature 326, 727;1987 and 326, 627$628 ; 1987)$ implying that a prospective foreign contribution of 15 per cent to the proposed US space station, worth perhaps $\$ 2,000$ million, counts for nothing against the encumbrance of having strings attached? No official of the Japanese government (which is perpetually in hock to its would-be pensioners) would be allowed to behave in such a cavalier fashion. Is that another lesson in competitiveness to be learned?

\section{Mentally speaking}

\section{The British Royal Family has an opportunity to foster openness on psychiatric illness.}

THE British royal family has been embarrassed, in the past few weeks, by the disclosure (originally in The Times) that three cousins of the present Queen have been confined in a psychiatric hospital for more than three decades. Part of the difficulty is that the need for such treatment should have arisen in the first place. Another is that the unfortunate people affected should have been been confined (admittedly when that was the standard method of treatment), but then kept confined when the ill-effects of institutionalization were recognized about a quarter of a century ago. It may also be mildly embarrassing, to a family whose genealogy must be better known than even that of Abraham's family, that these distressing circumstances had hitherto escaped attention.

In the monarchies of Western Europe, the guiding principle seems to be that royal families typify and, by so doing, dignify what may be called ordinary families. If anything, the British royal family has done a little better than might have been expected. Confining the psychiatrically sick and the mentally defective was common just a few decades ago. More recently, the Prince of Wales, the monarch in waiting, has taken an active part in several good causes of this kind. He has lent his name to an appeal for funds for schizophrenia research. Last September, at the Harvard anniversary celebrations, he made an eloquent plea for a better understanding of the "dark side" of human nature. May he, and his relatives, now be emboldened to go a little further?

One of the startling anomalies of the present time is the contrast between the persistence of reticence about psychiatric illness and the explicitness with which the problem of AIDS (acquired immune deficiency syndrome) is discussed. The explanation is not difficult. Although AIDS is mostly a venereal disease, and thus shaming, there is also a danger that there will be an epidemic and thus an urgent need for public education, with the result that reticence is overridden. Psychiatric illness is also shaming, partly because of the general belief that it "runs in families", itself supported by observations such as that a few weeks ago that, among the Amish of southern Pennsylvania, the propensity to manic-depressive illness is genetically determined. The irony is that the concealment of most families' shame contributes directly to their individual sense of having to carry a secret burden. When he has a chance, the Prince of Wales might do a power of good by making a few kind remarks about his forgotten relatives. 